\title{
Pelaksanaan Tata Kelola Administrasi Data Kesiswaan Di Madrasah Tsanawiyah Darul Jannah Muara Burnai II
}

\author{
B. Santoso', Kms. Badarudin², Saipul Annur ${ }^{3}$ \\ ${ }^{1}$ STAI Assidiqiyah Lempuing Jaya, Indonesia \\ 2,3Universitas Islam Negeri Raden Fatah Palembang, Sumatera Selatan, Indonesia \\ 1santoso7815@gmail.com
}

\begin{abstract}
This study aims to see how far the system of implementing administrative governance is at Madrasah Tsawawiyah Darul Jannah Muara Burnai II, Ogan Komering Ilir Regency. This study aims to analyze, and describe the process of implementing the administrative governance of Ogan Komering Ilir Regency. The data collection technique uses observation, interviews, and documentation studies, and the data analysis uses reduction, data display, and drawing conclusions. The results obtained include the implementation of administrative governance at MTs Darul Jannah Muara Burnai II, through the planning process and service improvement carried out by the madrasa administration manager by analyzing the needs of madrasa residents at the end of each semester. make data on the submission of madrasa needs, in coordination with the head of the madrasa, then the manager and the head of the madrasa find the services needed. The inhibiting factors are the lack of infrastructure, personnel who are not in accordance with their educational background, and the rules that often change. while the supporting factors are, the existence of adequate resources, a conducive work climate and full of kinship, motivation, a high sense of responsibility, and dedication to work.
\end{abstract}

Keywords: Implementation, Administrative Governance, Factors

\begin{abstract}
Abstrak. Penelitian ini melihat sejauhmana sistem pelaksanaan tata kelola administrasi, di Madrasah Tsawawiyah Darul Jannah Muara Burnai II, Kabupaten Ogan Komering Ilir. Penelitian ini bertujuan untuk menganalisis, dan mendiskripsikan proses pelaksaan tata kelola administrasi Kabupaten Ogan Komering Ilir. Teknik pengumpulan datanya menggunakan observasi, wawancara,dan studi dokumentasi, dan analisis datanya menggunakan Reduksi, Display data, dan penarikan kesimpulan. Hasil penelitian diperoleh diantaranya adalah Pelaksanaan tata kelola administrasi di MTs Darul Jannah Muara Burnai II, melalui proses perencanaan dan peningkatan layanan yang dilakukan oleh pengelola administrasi madrasah dengan cara melakukan analisis terhadap kebutuhan warga madrasah disetiap akhir semester. membuat data pengajuan kebutuhan madrasah, dengan berkoordinasi dengan Kepala Madrasah, kemudian pengelola beserta Kepala Madrasah, mengidentifikasi layanan yang dibutuhkan. Adapun faktor penghambatnya adalah, kurangnya sarana prasarana, personilyang tidak sesuai latar belakang pendidikanya, dan adanya aturan yang sering berubah-ubah. sedangkan faktor pendukungnya adalah, adanya sumber daya yang cukup kompeten, iklim kerja yang kondusif dan penuh kekeluargaan, motivasi, rasa tanggung jawab dan dedikasi terhadap pekerjaan yang tinggi.
\end{abstract}

Kata Kunci: Pelaksanaan, Tata KelolaAdministrasi, Faktor-faktor

\section{PENDAHULUAN}

Salah satu aspek yang memiliki peranan penting dan menentukan dalam keberhasilan dalam suatu organisasi adalah terwujudnya tatanan dan pengelolaan administrasi yang baik. Didasarkan atas dasar-dasar yang tepat, dan di dukung oleh adanya sumberdaya manusia yang kompeten, serta mumpuni dibidangnya masing-masing (Aziz, 2016). Pengelolaan administrasi 
disekolah atau madrasah akan menjadi tertib, jika di tangani oleh personalia yang memiliki skill dan kemampuan,dedikasi, dan pengabdian yang baik pula, demi terwujudnya tujuan organisasi, atau lembaga pendidikan sesuai dengan yang diharapkan yaitu terwujudnya administrasi yang tertib, tertata, sistematis sesuai dengan tugas pokok dan fungsinya masing-masing,

Adapun tujuan administrasi adalah agar semua kegiatan saling mendukung tercapainya tujuan pendidikan. Dengan kata lain, administrasi yang digunakan dalam dunia pendidikan diusahakan untuk mencapai tujuan sederhana. Kalimat yang sederhana ini sebetulnya mengandung makna yang mendalam karena di dalam dunia pendidikan melibatkan banyak orang yang masing-masing harus melakukan kegiatan sendiri-sendiri secara teratur, sekaligus melakukan kegiatan yang sama untuk mencapai tujuan pendidikan (Aziz, 2016). Adapun bidang tugas yang harus dikelola didalam administrasi sekolah antara lain mencakup administrasi kurikulum, kesiswaan, pendidik dan tenaga kependidikan, sarana prasarana, pembiayaan, HUMAS, bimbingan konseling dan administrasi persuratan (Patsun, 2015).

Setiap organisasi dari berbagai bentuk, jenis, dan tujuan terdiri atas dua pekerjaan yaitu aktivitas substantif dan pekerjaan kantor. Organisasi sekolah mempunyai aktivitas substantif berupa kegiatan pembelajaran, yang dilaksanakan oleh guru, sedangkan pekerjaan kantor pada suatu madrasah berupa layanan administrasi madrasah yang dilaksanakan oleh petugas tata kelola administrasi sekolah atau madrasah. Tata laksana pendidikan sering disebut dengan istilah administrasi tata usaha, yaitu segenap proses kegiatan pengelolaan surat-menyurat yang dimulai dari menghimpun (menerima), mencatat, mengelola, menggandakan, mengirim dan menyimpan semua bahan keterangan yang diperlukan oleh organisasi (Arikunto dan Yuliana, 2008).

Tata kelola dapat diartikan sebagai cara untuk mengatur dan mengendalikan hubungan antar pihak manajeman dengan pihak yang berkepentingan (stakeholder) terhadap organisasi, dalam pelaksanaanya tata kelola berfungsi untuk mengatur proses, kebiasaan, kebijakan,terkait lembaga yang mempengaruhi pengarahan, pengelolaan serta pengontrolan suatu institusi (Noor dan Rahmatillah, 2018). Tata kelola administrasi sekolah atau madrasah adalah segala bentuk usaha untuk mencatat, berbagai kegiatan dalam mencapai tujuan pendidikan di sekolah. Secara spesifik, pegawai tata kelola administrasi dapat, dirumuskan sebagai segenap rangkaian kegiatan yang meliputi, menghimpun data, mencatat data, mengolah data, menggandakan data, mengirim data, dan menyimpan keterangan-keterangan untuk kepentingan pembuatan kebijakan(Liang, 2007). Dalam bagian lain disebutkan bahwa pengelolaan itu sama halnya dengan manajemen yang artinya tata kelola sehingga menghasilkan tata kelola yang baik, sesuai dengan yang direncanakan(Jamal, 2018).

Setiap pengelolaan administrasi pada suatu organisasi tentunya memiliki standar sebagai jaminan adanya kepastian bagi pemberi didalam pelaksanaan tugas dan fungsinya. Hal ini sebagaimana pendapat Agung Kurniawan (2015) bahwa indikator penilaian profesionalisme tata kelola 
$\overline{\text { administrasi, diantaranya adalah Equality, perlakuan yang sama diberikan pada }}$ masyarakat pendidikan terkait administrasi madrasah, Equity, perlakuan yang sama kepada masyarakat pendidikan secara adil dan adanya kesetaraan, Loyality, kesetiaan diberikan kepada organisasi. Berbagai jenis kesetiaan tersebut terkait satu sama lain dan tidak ada kesetiaan yang mutlak diberikan kepada satu jenis kesetiaan tertentu dengan mengabaikan yang lain, dan Accountability, siap menerima tanggung jawab atas apapun yang dikerjakan dan harus menghindarkan diri dari sindroma sekedar melaksanakan perintah atasan.

Lembaga pendidikan seperti organisasi sekolah atau madrasah, merupakan kerangka kelembagaan di mana administrasi dapat berperan dalam mengelola organisasi untuk mencapai tujuan yang telah ditetapkan. Dilihat dari tingkatan-tingkatan suatu organisasi dalam hal ini sekolah/madrasah, administrasi dapat dilihat dalam tiga tingkatan yaitu tingkatan institusi (institutional level), tingkatan manajerial (managerial level), dan tingkatan teknis (technical level). Tingkatan institusi berkaitan dengan hubungan antara lembaga pendidikan (sekolah/madrasah) dengan lingkungan eksternal, tingkatan manajerial berkaitan dengan kepemimpinan, dan organisasi lembaga (sekolah/madrasah), dan tingkatan teknis berkaitan dengan proses pembelajaran.

Administrasi tidak hanya dilakukan dalam waktu tertentu saja tetapi setiap hari secara sistematis. Keberhasilan pendidikan di madrasah harus ditunjang oleh pelayanan administrasi madrasah yang bermutu. Menurut Yusuf Hadijaya bahwa administrasi sebagai proses rangkaian kegiatan memiliki unsur sebagai organisasi, manajemen, komunikasi, kepegawaian, keuangan, sarana prasarana, ketatausahaan dan hubungan masyarakat (Hadijaya, 2012).

Administrasi akan berhasil baik apabila didasarkan atas dasar-dasar yang tepat. Menurut Rosmiaty, ia menyatakan bahwa beberapa dasar yang perlu diperhatikan agar administrator dapat mencapai sukses dalam tugasnya diantaranya prinsip efisiensi, prinsip Pengelolahan, prinsip pengutamaan tugas pengelolaan, prinsip kepemimpinan yang efektif dan prinsip Kerjasama (Aziz, 2016). Selain harus mempunyai dasar - dasar yang tepat, Veithzal Rivai dalam bukunya Manajemen Sumber Daya Manusia untuk Perusahaan, menjelaskan bahwa agar pengembangan administrasi madrasah dapat tercapai sesuai dengan yang diinginkan dan tidak sia-sia, maka ada beberapa langkah yang harus dilakukan oleh Kepala Madrasah, diantaranya penentuan sasaran, penetapan isi program, identifikasi prinsip-prinsip belajar, pelaksanaan program, identifikasi manfaat, dan penilaian pelaksanaan program (Rivai, 2005).

Berdasrakan Permendiknas Nomor 24 Tahun 2008 bahwa kompetensi tenaga administrasi meliputi kompetensi kepribadian, kompetensi sosial, kompetensi teknis dan kompetensi manajerial (Permendiknas No. 24, 2008). Staf Tata Usaha (TU) mempunyai peranan yang penting dalam membantu mengembangkan sekolah menjadi lebih maju dan berkualitas. Tenaga 
administrasi sekolah berfungsi sebagai juru kelola administrasi sekolah yang berkaitan dengan pengelolaan data siswa, data pendidik dan data kependidikan, persuratan, arsip administrasi sarana prasarana dan administasi keuangan (Puardi, 2019).

Setiap individu (Kepala Madrasah, guru, staf, pegawai Tata Usaha) tentunya memiliki kompetensi yang berbeda-beda dalam bidang tata kelola administrasi. Perbedaan tersebut dapat dilatarbelakangi oleh berbagai factor baik dari dalam diri sendiri maupun dari luar diri. Faktor dari dalam diri maupun dari luar diri yang melatarbelakanginya sehingga perlu diperhatikan agar dapat memilih dan memilah saat dihadapkan pada berbagai kondisi yang mungkin terjadi. Faktor Personal dan faktor kepemimpinan merupakan faktor-faktor yang mempengaruhi individu diantaranya kepala madrasah, guru, staf, pegawai tata usaha dalam tata kelola administrasi (Yamin dan Maisah, 2010).

Namun, berdasarkan observasi dan wawancara yang dilakukan peneliti pada tanggal 26 Maret 2020 dengan Kepala Tata Usaha Administrasi Madrasah Tsanawiyah Darul Jannah Muara Burnai II, Kecamatan Lempuing Jaya Kabupaten Ogan Komering Ilir, menerangkan bahwa terdapat sebanyak 22 tenaga pendidik,dan dua diantaranya sekaligus merangkap sebagai pegawai Tata Usaha, atau tata kelola administrasi, dan satu orang operator madrasah (HS Hidayatullah, Wakil Kepala Madrasah). Meskipun tenaga administrasi sudah ada, akan tetapi dirasa masih jauh dari cukup, dan sesuai dengan rasio ideal dan peraturan dalam pengelolaannya, kepala tata usaha mengaku mengalami kesulitan dalam proses pengorganisasiannya, ditengah keterbatasan sumber daya dan personel yang ada.

Ditemukan beberapa kenyataan yang menunjukan adanya masalah terkait pengelolaan tenaga administrasi, yaitu pembagian tugas yang belum merata, sesuai dengan tugas pokoknya masing-masing, adanya faktor senior dan yunior dalam melaksanakan tugas, kompetensi administrasi yang belum terpenuhi baik itu kompetensi kepribadian, sosial, teknis maupun manajerial. Selain itu juga karena adanya rangkap jabatan, dimana adanya tenaga pendidik sekaligus merangkap sebagaitenaga administrasi, dan belum sesuainya latar belakang pendidikan pegawai administrasi,dengan pekerjaan yang dihadapinya. Serta masih terbatasnya sarana dan prasarana pendukung yang ada, sebagai modal utama dalam pekerjaan. Sehingga pada akhirnya sistem pelaksanaan tata kelola administrasi disekolah tersebut dinilai masih cendrung kurang tertata, tersusun secara sistematis sesuai dengan tugas pokok dan fungsi (Tupogsi)nya masing-masing, dan setiap tugas keadministrasian sekolahpun, hanya dikerjakan secara bersama-sama, bagi mereka yang memiliki waktu luang, meskipun sebenarnya bukanlah tugas mereka, hanya karena faktor kasihan dan lain sebagainya. Hal inilah yang mendorong peneliti untuk mengadakan penelitian lebih lanjut dan mendalam, terkait permasalahan diatas, dan hal-hal apa saja yang mempengaruhinya, sehingga sistem pelaksanaan tata kelola administrasi madrasah belum berjalan sebagai mana idealnya, atau mungkin ada faktor-faktor lain yang 
$\overline{\text { menjadi kendala utamanya, sehingga pada akhirnya penelitian ini diharapkan }}$ bisa memberi kontribusi serta sumbangsihnya pemikiran, bagi kemajuan tatakelola administrasi madrasah, khususnya di MTs. Darul Jannah Muara Burnai II.

Beberapa faktor-faktor yang mempengaruhi kinerja tenaga administrasi sekolah atau madrasah dibagi dua yaitu secara intenal maupun secara eksternal. Adapun secara internal meliputi kemampauan dan keahlian, pengetahuan, kepribadian, serta motivasi kerja (Kasmir, 2016). Sedangakan secara eksternal meliputi kepemimpinan, iklim kerja dan sarana prasarana (Majid, 2016). Adapun kepemimpinan menurut Clark dalam Noor adalah serangkian aktifitas yang dapat diamatipada orang lain yang terjadi dalam suatu kelompok atau organisasi yang terdiri dari seorang pemimpin dan pengikut yang dengan kerelaan mencapai tujuan umum dan bekerjasama untuk meraihnya (Noor, 2020)

Adapun tujuan penelitian ini adalah untuk menganalisis pelaksanaan tata kelola administrasi di MTs Darul Jannah Muara Burnai II Kabupaten Ogan Komering Ilir dan menganalisis faktor-faktor yang mempengaruhi pelaksanaan tata kelola administrasi, di MTs Darul Jannah Muara Burnai II, Kabupaten Ogan Komering Ilir.

Beberapa penelitian terdahulu yang telah dilakukan, seperti penelitian Nur Jamal dan Masykurotus Syarifah penelitianya bertujuan untuk mendeskripsikan pengelolaan administrasi dalam peningkatan mutu pendidikan. Konklusi yang diambil peneliti adalah bahwa pengelolaan administrasi pendidikan di lembaga pendidikan sangatlah penting, karena dengan pengelolaan yang baik dalam proses pembelajaran, maka lembaga pendidikan dapat meningkatkan mutu pendidikannya. Dengan demikian, maka pengelolaan administrasi mulai dari perencanaan, pelaksanaan, dan pengawasan menjadi salah satu yang cukup dominan dalam melakukan penilaian serta peningkatan mutu pendidikan pada sebuah lembaga pendidikan (Jamal dan Syarifah, 2018). Patsun, penelitianya bertujuan untuk mendeskripsikan paradigma administrasi dalam pengelolaan sekolah yang menyatakan bahwa munculnya paradigma baru dalam pengelolaan pendidikan yang berorientasi pada kegiatan pelayanan setidaknya berimplikasi luas dalam administrasi dan pengelolaan sekolah dengan meletakkan partisipasi, transparansi dan akuntabilitas dalam pelaksanaan administrasi kurikulum dan pembelajaran, administrasi kesiswaan, administrasi pendidik dan tenaga kependidikan, administrasi sarana dan prasarana pendidikan, administrasi keuangan atau pembiayaan, administrasi program hubungan sekolah dengan masyarakat, administrasi program bimbingan dan konseling, dan administrasi persuratan yang harus selalu diperhatikan oleh kepala sekolah maupun pengawas selaku pembina, pembimbing dan penilai kinerja sekolah (Patsun, 2015). Sedangkan, Amirudin, penelitianya bertujuan untuk mendeskripsikan kinerja pegawai tata usaha dengan mutu layanan administrasi di madrasah. Hasil penelitian menyimpulkan bahwa kinerja pegawai tata usaha di Madrasah harus 
ditingkatkan lagi, khususnya pada bidang ketatausahaan, agar melakukan kegiatannya berdasarkan standar operasional prosedur (SOP) yang berlaku di madrasah, agar dapat memberikan kepuasan terhadap seluruh pengguna layanan sekolah baik guru, siswa, orang tua, masyarakat maupun lembaga. Dengan demikian, semakin baik kinerja pegawai tata usaha maka akan semakin baik juga mutu layanan administrasinya (Amirudin, 2017).

Melihat hasil penelitian-penelitian terdahulu memperlihatkan perbedaan dengan penelitian yang dibahas oleh penulis saat ini yaitu penelitian saat ini menggambarkan bagaimana pengelolaan tata kelola administrasi yang ada di Darul Jannah Muara Burnai II serta apa saja yang mempengerahui pelaksaan tata kelola administrasi yang ada, baik faktor yang mendukung maupun yang menghambat.

\section{METODE PENELITIAN}

Jenis penelitian yang digunakan adalah penelitian deskriptif dan menggunakan pendekatan kualitatif. Menurut Sugiono penelitian kualitatif adalah suatu cara ilmiah (rasional, empiris, dan sistematis) untuk memperoleh data empiris (yang teramat oleh indra manusia, valid, reliabel, dan objektif dengan tujuan dan kegunaan (penemuan, pembuktian, atau pengembangan pengetahuan, tindakan dan produk) tertentu (Sugiyono, 2011:3). Pendekatan yang digunakan dalam penelitia ini adalah pendekatan kualitatif. Data yang diperoleh meliputi transkip interview, catatan lapangan berupa foto, dokumen pribadi dan lan-lain yang menggambarkan bagaimana pelaksanaan tata kelola administrasi pada siswa di Madrasah Tsanawiyah Darul Jannah Muara Burnai II Kabupaten Ogan Komering Ilir dilaksanakan dan apa saja faktor pendukung dan penghambat proses pelaksanaan tata kelola administrasi tersebut. Analisis data dilakukan dengan mereduksi data, penyajian data dan penarikan kesimpulan.

\section{HASIL DAN PEMBAHASAN}

\section{Pelaksanaan Tata Kelola Administrasi di MTs Darul Jannah}

Sebagai sebuah lembaga pendidikan termasuk juga madrasah, di dalam penyelenggaranya pastilah terdapat berbagai macam kegiatan. Kegiatan ini memerlukan perencanaan, pengarahan, pengkoordinasian, pengontrolan, dan pengkomunikasian, agar benar-benar berdaya guna untuk mencapai tujuan yang di harapkan. Pelaksanaan tata kelola administrasi madrasah, dalam meningkatkan mutu pelayanan di MTs Darul Jannah Muara Burnai II meliputi: perencanaan, pelaksanaan dan evaluasi. adapun lebih jelasnya akan diuraikan berikut ini.

1. Perencanaan tata kelola administrasi di MTs Darul Jannah

Perencanaan tata kelola administrasi dapat diartikan sebagai pelaksanaan suatu pekerjaan yang terarah yang dilakukan oleh sumber daya pegawai tata usaha untuk mencapai tujuan yang telah ditentukan oleh MTs Darul Jannah. 
Adapun pekerjaan yang dilakukan oleh pegawai tata usaha di MTs Darul Jannah dalam kaitannya dengan peningkatan mutu pelayanan, diantaranya selalu melihat kebutuhan siswa maupun pendidikan, yaitu dengan mengoptimalkan sumber daya pegawai Tata Usaha/administrasi yang ada, dan juga selalu mengupayakan memenuhi segala kebutuhan madrasah. Mulai dari tenaga pegawai yang profesional sesuai dengan job deskription-nya, peningkatan sarana prasarana dan juga peningkatan kualitas pendidikan di madrasah.

Perencanaan tata kelola administrasi di MTs Darul Jannah dilakukan dengan proses yang sistematis, dalam satu tahun sekali, yaitu pengelola bagian tata kelola administrasi madrasah melibatkan para guru dan staf, untuk mengadakan rapat bersama, dalam rangka menyampaikan laporan terhadap pelayanan madrasah yang harus diperbaiki, maupun diperbaharui oleh madrasah. Perencanaan ini dibuat sesuai dengan aspek-aspek yang dibutuhkan, mulai dari kebutuhan siswa hingga kebutuhan pendidikan. Untuk peningkatan sarana prasarana, dana yang dibutuhkan diperoleh dari dana pemerintah, dengan cara mengajukan proposal kepada pemerintah daerah. Selain itu dana juga diperoleh dari BOS (Bantuan Operasional Sekolah), baik yang bersumber dari pemerintah pusat (APBN), maupun pemerintah daerah (APBD) sertasumber lain yang tidak mengikat.

Perencanaan pelayanan di MTs Darul Jannah dilakukan dengan proses yang sistematis dalam satu tahun sekali, yaitu pengelola bagian Pegawai Tata Kelola Administrasi, melibatkan para guru dan staf untuk mengadakan rapat bersama, dalam rangka menyampaikan laporan pelayanan, yang harus diperbaiki maupun diperbaharui. Perencanaan manajemen Pegawai Tata Kelola Administrasi yang diterapkan dilakukan dengan bermusyawarah dan terkoordinir oleh pengelola administrasi dengan para guru dan staf sekolah dalam agenda rapat tahunan. Manajemen administrasi sebelum melakukan perencanaan, diadakan pengecekan layanan agar dalam merencanakan peningkatan layanan bisa berjalan dengan efektif dan efisien.

Sesuai dari hasil penelitian serta wawancara kepada bapak Imam Rohani, S.Pd.I, selaku Kepala MTs Darul Jannah telah melaksanakan perencanaan secara sistematis mulai dari pengecekan hingga mengadakan perencanaan layanan. Menurut beliau, MTs Darul Jannah melakukan perencanaan kebutuhan siswa.Peningkatan layanan sesuai dengan perencanaan yang telah ditentukan dalam penyusunan program dan anggaran madrasah. Prosedur dalam peningkatan layanan terdiri dari perencanaan, pelaksanaan dan pelaporan di setiapahirtahunajaran.

Proses perencanaan peningkatan layanan dilakukan oleh pengelola administrasi madrasah, dengan cara melakukan analisis kebutuhan warga madrasah dan pendidikan, disetiap akhir semester. Setelah itu, pengelola administrasi bertanggungjawab, membuat data pengajuan kebutuhan siswa dan selalu berkoordinasi dengan Kepala Madrasah, kemudian pengelola beserta Kepala Madrasah mengidentifikasi layanan yang 
dibutuhkan. Pelaksanaan peningkatan layanan di MTs Darul Jannah adalah dengan cara: data kebutuhan siswa disetujui oleh Kepala Madrasah, kemudian melaksanakan rapat pemilihan pengembangan pelayanan. Setelah disetujui, pengelola melaksanakan pengembangan pelayanan yang telah direncanakan.

2. Pelaksanaan tata kelola administrasi di MTs Darul Jannah

Ibnu Syami dalam Purnama menjelaskan bahwa pelaksanaan ataupun actuating adalah usaha untuk menciptakan iklim kerja sama diantara staf pelaksanaan program sehingga tujuan organisasi dapat tercapai secara efektif dan efisien (Purnama, 2020).

Melihat dari defenisi diatas Pelaksanaan tata kelola administrasi merupakan proses berlangsungnya kegiatan pelayanan, membantu, dan memenuhi atau menyediakan segala kebutuhan penunjang di madrasah. Jadi pengelolaan administrasian adalah proses interaksi, antara petugas ketatausahaan dengan warga madrasah, yaitu murid/siswa dalam rangka memberikan pelayanan kepada siswa demi tercapainya tujuan. Dalam fungsi ini memuat kegiatan pengorganisasian dan kepemimpinan tata kelola administrasi yang melibatkan penentuan berbagai kegiatan, seperti pembagian pekerjaan ke dalam berbagai tugas khusus, yang harus dilakukan setiap petugas administrasi madrasah, dalam proses pelayanan jasa kepada warga madrasah.

Dalam pelaksanaan tata kelola administrasi, MTs Darul Jannah mengoptimalkan sumber daya pegawai tata kelola administrasi yang ada, dan melihat kebutuhan serta pengembangannya. Sehingga nantinya prosesnya bisa berjalan baik dan lancar. Madrasah merealisasikannya dengan tenaga pegawai yang cukup profesional sesuai dengan job description dari dua tenaga administrasi, yang masing-masing mempunyai tugas dalam surat-menyurat (berkas/dokumen), melayani pelaksanaan pekerjaan operatif madrasah dan keuangan. Disamping itu, juga peningkatan dalam sarana prasarana, berkomunikasi dengan baik dan jelas, dan memberikan pelayanan secara cepat dan tepat.

Dalam pengorganisasian manajemen tata kelola administrasi yaitu dengan pembagian dimasing-masing bidang seperti kepegawaian, kurikulum, kesiswaan, dan keuangan. Petugas yang punya wewenang dituntut untuk senantiasa menjaga tanggungjawab terhadap tugasnya. Supaya dalam pelaksanaan administrasi yang ada berjalan dengan baik. Kemudian dalam kegiatan pendayagunaan, pihak madrasah selalu berupaya untuk meningkatkan kinerja administrasi, yaitu dengan peningkatan kualitas kepegawaian, pengembangan sarana prasarana dan pelayanannya.

Pelaksanaan adalah upaya untuk menggerakkan atau mengarahkan tenaga kerja, serta mendayagunakan fasilitas yang ada. Salah satu upaya tersebut adalah pengembangan dan pemeliharaan. Pengembangan ialah sebuah kegiatan menambah atau merubah sesuatu, agar lebih meningkat dan baik lagi. Manajemen administrasi di MTs Darul Jannah dalam 
merealisasikan pelayanannya menggunakan dua tahapan yaitu, pengembangan dan pemeliharaan. Sedangkan berdasarkan temuan data hasil observasi yang peneliti lakukan di MTs Darul Jannah, tanggal 6-9 September tahun 2020, bahwa pengembangan dan pemeliharaan pelayanan dimaksudkan, agar proses pelayanan senantiasa mempunyai peningkatan dan berjalan dengan baik. Kemudian untuk hal apa saja yang perlu ditingkatkan dalam pelayanan, pihak manajemen madrasah mengadakan pertemuan atau rapat dengan wali murid, atau bertanya secara langsung ketika penerimaan raport siswa di akhir semester. Hal ini dilakukan untuk mengetahui sampai mana kinerja pelayanan madrasah. Disamping itu, mengenai ketersediaan sarana prasarana, madrasah senantiasa berupaya untuk meningkatkan kualitas pelayanan pendidikan terhadap siswanya. Hal ini dapat dilihat dari upaya sekolah untuk menyediakan sarana prasarana yang sesuai dengan kebutuhan. Pendistribusian yang diterapkan di MTs Darul Jannah, kegiatan pendistribusian berjalan dengan cukup baik.

Pelaksanaan kegiatan administrasi di MTs Darul Jannah mencakup 6 (enam) jenis kegiatan, yaitu:

1) Menghimpun, merupakan kegiatan-kegiatan mencari data mengusahakan tersediannya segala keterangan yang tadinya belum ada, sehingga siap untuk dipergunakan bilamana diperlukan.

2) Mencatat, merupakan kegiatan membubuhkan dengan berbagai peralatan tulis keterangan yang diperlukan sehingga terwujud tulisan yang dapat dibaca, dikirim dan disimpan. Dalam perkembangan teknologi modern maka dapat termasuk alat-alat perekam suara.

3) Mengolah, merupakan bermacam kegiatan mengerjakan keteranganketerangan dengan maksud menyajikan dalam bentuk yang lebih berguna.

4) Menggandakan, merupakan kegiatan memperbanyak dengan berbagai cara dan alat.

5) Mengirim, merupakan kegiatan menyampaikan dengan berbagai cara dan alat dari satu pihak kepada pihak lain.

6) Menyimpan, merupakan kegiatan menaruh dengan berbagai cara dan alat di tempat yang tertentu yang aman.

3. Evaluasi tata kelola administrasi di MTs Darul Jannah

Menurut Salim dalam Inderiyeni bahwa evaluasi adalah kegiatan dengan sungguh-sungguh mengamati, mengoreksi, menimbang baik buruknya suatu masalah yang dilakukan oleh suatu tim secara formal dengan dasardasar tertentu kemudian member penghargaan seberapa besar bobotnya, kualitasnya, atau kemampuannya, (Inderiyeni, 2017: 19-20).

Merujuk pada beberapa pengertian evaluasi diatas dapat diartikan Evaluasi merupakan suatu upaya untuk mengetahui berapa banyak hal-hal yang telah dirasakan oleh siswa dari hal-hal yang telah diberikan oleh petugas ketatausahaan. Untuk dapat menentukan tercapai dan tidaknya tujuan pelayanan pendidikan perlu dilakukan usaha dan tindakan atau 
kegiatan untuk menilai hasil pelayanan. Penilaian hasil pelayanan bertujuan untuk melihat kemajuan pelayanan dalam hal meningkatkan mutu pelayanan sesuai tujuan yang telah ditetapkan.

Kegiatan evaluasi sudah pasti dilakukan oleh semua lembaga pendidikan, termasuk di MTs Darul Jannah. Kegiatan pengawasan dilakukan minimal dua kali setiap enam bulan (satu semester) sekali, dengan cara melibatkan Wakil Kurikulum, untuk melaporkan berkaitan dengan keluhan tentang pelayanan, yang perlu diperbaiki maupun ditingkatkan. Pengawasan dilaksanakan dengan cara melihat kondisi kebutuhan pelanggan atau siswa, guru dan wali murid.

Proses evaluasi dilaksanakan dengan proses mempertimbangkan beberapa keluhan. Jika keluhan tersebut mengenai hal yang yang mendasar dalam pelayanan, komunikasi maupun sikap dalam pelayanan, maka yang dilakukan adalah merubah cara berkomunikasi, kinerja dan sikap dalam pelayanan sehingga tidak timbulnya keluhan yang sama.

\section{Faktor-faktor yang Mempengaruhi Pelaksanaan Tata Kelola Administrasi di MTs Darul Jannah}

Pelaksanaantata kelola administrasi di MTs Darul Jannah tentunya dipengaruhi oleh beberapa faktor, diantaranya faktor internal dan eksternal.

\section{a. Faktor Internal}

Faktor yang terkait dengan seluruh pribadi pegawai tata kelola administrasi di MTs Darul Jannah Muara Burnai II, yang mempengaruhi kinerjanya, adapunfaktor-faktortersebutantara lain :

1) Kemampuan pegawai tata kelola administrasi MTs Darul Jannah dipengaruhi pengetahuan (knowledge) dan keterampilan (skill).

2) Kepala sekolah berperan aktif, dalam meningkatkan pengetahuan pegawai tata kelola administrasi dalam meningkatkan ketakwaan kepada Allah swt. dan kemajuan IPTEK.

3) Mengikuti kegiatan pelatihan, diklat dan sosialisasi sistem administrasi madrasah yang diselenggarakan oleh Departemen Agama di Kabupaten Ogan Komering Ilir.

4) Pegawai tata kelola administrasi di MTs Darul Jannah cukup berminat mengerjakan sekolah tugas administrasi madrasah.

5) kesadaran pegawai tata kelola administrasi terhadap tugas pokok dan fungsinya serta kepuasan yang dirasakan pegawai ketika bisa dan adanya tuntutan sistem pekerjaan administrasi madrasah yang serba komputerisasi dan sistem online serta adanya pengawasan dari Kepala Madrasah.

\section{b. Faktor eksternal}

Faktor yang bersumber dari luar individu, dalam hal ini adalah dari luar individu pegawai tata kelola administrasi di MTs Darul Jannah, diantaranya: 
1) Kepala Madrasah selaku pimpinan telah berperan secara eksternal dalam mendorong kinerja tata kelola administrasi dengan cara memberikan pengarahan dan motivasi, menjalin koodirnasi dan komunikasi yang baik dengan pegawai Tata Usaha, serta dapat menciptakan suasana yang nyaman di lingkungan madrasah.

2) sarana dan prasarana yang mendukung kinerja pegawai Tata Usaha di MTs Darul Jannah masih belum memadai. Dikarenakan hanya didukung oleh satu ruang kerja, set komputer, dan lemari. Padahal untuk mengerjakan administrasi madrasah diperlukan sarana dan prasarana yang memadai yaitu satuorang pegawai, sedangkan pegawai Tata Usaha di MTs Darul Jannah berjumlah 2 orang, dan ini dirasa masih sangat jauh dari ideal dan cukup.

Dari penjabaran hasil penelitian yang dilakukan oleh peneliti mengenai pelaksanaan tata kelola administrasi yang ada di Madrasah Tsanawiyah Darul Jannah sudah sesuai dengan teori yang ada bahwa administrasi akan berhasil baik apabila didasarkan atas dasar-dasar yang tepat.yaitu prinsip efisiensi, prinsip pengelolahan, prinsip pengutamaan tugas pengelolaan, prinsip kepemimpinan yang efektif dan prinsip kerjasama (Aziz, 2016).

\section{KESIMPULAN}

Setelah di adakan penelitian di madarasah Tsanawiyah Darul Jannah Muara Burnai II, Kabupaten Ogan Komering Ilir, terkait sistem pelaksaan tatakelola administrasi disekolah tersebut maka dapatlah ditarik sebuah kesimpulan bahwa Pelaksanaan tatakelola, mulai dari proses, pelaksanaannya hingga evaluasi secara umum,sudah berjalan dengan dengan baik, sistematis, sesuai dengan tugas pokok dan fungsinya masing-masing, adanya sistem bertanggung jawab dan koordinasi yang baik dari seluruh stageholder administrasi secara berkala dan berjenjang, dan masih terdapatnya kekurangan sumberdaya tenaga dan sarana pendukung, bila di bandingkan dengan rasio kebutuhan beban kerja yang ada. Pelaksanaan tata kelola administrasi di MTs Darul Jannah tentunya dipengaruhi oleh beberapa faktor internal dan eksternal. Faktor internal diantaranya yaitu Kemampuan pegawai tata kelola administrasi, peran aktif kepala sekolah, kegiatan pelatiahan, minat pegawai administrasi dan kesadaran pegawai administrasi MTs Darul Jannah. Sedangkan faktor eksternal diantaranya yaitu motivasi kepala sekolah terhadap pegawai administrasi sekolah dan sarana prasarana yang ada di MTs Darul Jannah.

\section{DAFTAR PUSTAKA}

Amirudin. (2017). Kinerja Pegawai Tata Usaha dengan Mutu Layanan Administrasi di Madrasah. Al-Idarah: Jurnal Kependidikan Islam, 7 (I).

Arikunto, S., \& Yuliana, L, (2008). Manajemen Pendidikan. Yogyakarta: Aditya Media.

Azis, R. (2016). Pengantar Administrasi Pendidikan. Yogyakarta: Sibuku. 
Hadijaya, Y. (2012). AdministrasiPendidikan. Medan: Perdana Mulya Sarana. Inderiyeni. (2017). Evaluasi Layanan Sistem Perpustakaan di SMK Kehutanan Negeri Pekanbaru. Jurnal Pustaka Budaya, 4 (1), 19-20.

Jamal,N., \& Syarifah, M. (2018). Pengelolaan Administrasi dalam Peningkatan Mutu Pendidikan. Jurnal Kabilah, 2 (12).

Kasmir. (2016). Manajemen Sumber Daya Manusia: Teori dan Praktik. Depok: PT. Rajagrafindo Persada.

Kurniawan, A. (2015). Transformasi Pelayanan Publik. Yogyakarta: Pembaharuan.

Liang, L. G. (2007). Administrasi Perkantoran Modern. Yogyakarta: Liberty.

Madji, A. (2016). Pengembangan Kinerja Guru Melalui: Kompetensi, Komitmen dan Motivasi Kerja. Yogyakarta: Samudra Biru.

Noor, F. A. (2020). Manajemen, Tata Usaha, dan Kepemimpinan Raudatul Athfal. Jurnal Qurrod: Jurnal Pendidkan Islam Anak Usia Dini, 2 (1).

Noor, I., \& Rahmatillah, N. (2018). Inovasi Tata Kelola Sekolah Menengah atas (SMA) dalam Impelementasi Kebijakan Merdeka Belajar. Jakarta: Direktorat SMA.

Patsun. (2015). Paradigma Administrasi dalam Pengelolaan Sekolah, Gresik. Cendikia: Jurnal Studi Keislaman , 1, (2).

Permendiknas RI Nomor 24 Tahun 2008 tentang Standar Tenaga Administrasi Sekolah/Madrasah.

Puardi. (2018). Upaya Peningkatan Kompetensi staf tata usha dalam mengelolah administrasi Kepegawaian Melalui Pendampingan di SMA Negeri Sungai Beremes. Jurnal Manajemen Pendidikan, 3(1).

Purnama, A. (2020). Fungsi Actuating dalam Layanan Perpustakaan SMAIT di Kota Palembang. Studia Manageria: Jurnal Pendidikan Islam, 2 (2).

Rivai, V. (2005).Manajemen Sumber Daya Manusia untuk Perusahaan. Jakarta: RajaGrafindo Persada.

Sugiyono. (2011). Metode Penelitian Kombinasi (Mixed Methods), cet.1.Bandung: Alfabeta.

Yamin, M., \& Maisah. (2010). Standarisasi Kinerja Guru. Jakarta: Persada Press. 